\title{
Myocyte-Specific Enhancer Factor 2D
}

National Cancer Institute

\section{Source}

National Cancer Institute. Myocyte-Specific Enhancer Factor 2D. NCI Thesaurus. Code C92167.

Myocyte-specific enhancer factor 2D (521 aa, $56 \mathrm{kDa}$ ) is encoded by the human MEF2D gene. This protein plays a role in transcriptional regulation that affects skeletal and cardiac muscle development and differentiation of neurons. 